\title{
Pengaruh Literacy Financial, Experienced Regret, dan Overconfidence Terhadap Pengambilan Keputusan Investasi Di Pasar Modal
}

\section{Iskandar Budiman, Zefri Maulana \& Safwan Kamal}

Manajemen Keuangan Syariah, Fakultas Ekonomi dan Bisnis Islam, Institut Agama Negeri Islam Langsa

\begin{abstract}
This study aims to determine the effect of financial literacy, experienced regret, and overconfidence on investment decision making in the capital market. Method of this study was a quantitative approach. This study used nonprobability sampling and determined the number of samples from a population using quota sampling based on certain criteria in accordance with research conducted by researchers. The determined sample was 45 respondents. Respondents criteria were all investors who actively transact at least one day several times a transaction and a maximum of once a month transactions and investors who have experienced adverse events in stock investments such as losses but are still actively transacting. This study used a Likert scale measurement. The results of this study was based on a partial test showing that financial literacy did not affect investment decision making in the capital market, while experienced regret, and overconfidence affect investment decision making in the capital market. The conclusion of this study was based on the analysis of the coefficient of determination (adjusted R2) that 22.5\% of the variation in the value of investment decision making in the capital market at IAIN Langsa Investment Gallery was determined by three influential variables, namely financial literacy, experienced regret, and over-confidence. While the remaining $52.7 \%$ was explained by other variables not included in the equation above.
\end{abstract}

\section{Keywords:}

financial literacy, regrets experienced, excessive confidence, investment decisions

\section{Corresponding Author: \\ Zefri Maulana}

Fakultas Ekonomi dan Bisnis Islam, Institut Agama Negeri Islam

Langsa. Email: zefrimaulana@iainlangsa.ac.id

(C) The Author(s) 2021

DOI: https:/ / doi.org/ 10.36407/jmsab.v4i1.282

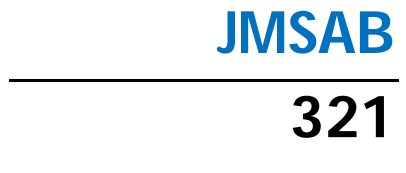

Research Paper

Management

Received: 26 Feb 2021

Accepted: 18 Jun 2021

Online: 25 Jul 2021

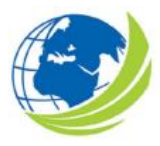

Jurnal Manajemen Strategi

dan Aplikasi Bisnis,

Vol 4, No. 2, 2021,

pp. $321-330$

eISSN 2655-237X

\section{(c)}

CC BY: This license allows reusers to distribute, remix, adapt, and build upon the material in any medium or format, so long as attribution is given to the creator. The license allows for commercial use. 


\section{PENDAHULUAN}

Perkembangan sektor jasa keuangan dalam pasar modal di Indonesia tidak lepas dari kualitas para pelaku yang melaksanakan tugas untuk mengoptimalkan sektor jasa keuangan. Dalam meningkatkan kualitas jasa keuangan, para pelaku yang bertugas untuk mengoptimalkan jasa keuangan harus memberikan informasi dan pengetahuan serta memberikan pemahaman kepada masyarakat, sehingga masyarakat lebih percaya untuk menginvestasikan modal kepada sektor jasa keuangan dalam pasar modal. Masyarakat atau para investor selalu memiliki pertimbangan dalam mengambil keputusan dikarenakan dalam berinvestasi selalu terdapat resiko. Tetapi semakin tinggi tingkat risiko maka semakin tinggi pula tingkat pengembalian keuntungan atau imbal hasil.

Institut Agama Islam Negeri Langsa, merupakan salah satu Perguruan Tinggi yang telah mempunyai Galeri Investasi. Dibukanya Galeri Investasi ini merupakan program kerja sama antara IAIN Langsa dengan Bursa Efek Indonesia (BEI), dan MNC Sekuritas sebagai mitra perusahaan sekuritasnya. Galeri Investasi ini dikelola oleh Fakultas Ekonomi dan Bisnis Islam di bagian Laboratorium.

Dengan adanya Galeri Investasi BEI diharapkan dapat saling memberikan manfaat bagi semua pihak sehingga penyebaran informasi pasar modal tepat sasaran serta dapat memberikan manfaat yang optimal bagi mahasiswa, akademisi, praktisi ekonomi, investor, pengamat pasar modal maupun masyarakat umum di daerah dan sekitarnya baik untuk kepentingan sosialisasi dan pendidikan/edukasi pasar modal maupun untuk kepentingan ekonomis atau alternatif investasi. Hingga tahun 2020 jumlah investor Galeri Investasi BEI IAIN Langsa sebanyak 200 Investor.

Investasi adalah menempatkan dana pada saat tertentu dengan harapan dapat menghasilkan keuntungan di masa depan sehingga untuk melakukan investasi para investor memerlukan informasi penting yang dapat menentukan pilihan investasi (Lubis 2013:5). Perkembangan dunia investasi semakin bertambah pada masyarakat, ada juga masyarakat yang beranggapan bahwa dengan melakukan investasi mendapatkan tambahan pendapatan. Pentingnya sektor jasa keuangan terutama dalam pasar modal untuk pembangunan ekonomi dalam bentuk investasi perlu didukung oleh sumber daya manusia yang berkualitas. Upaya untuk mendukung sumber daya manusia salah satunya dengan meningkatkan literasi keuangan (Financial Literacy). Menurut Wardani, A.K., \& Lutfi (2017), Literasi keuangan dapat diartikan sebagai pengetahuan keuangan dan kemampuan seseorang untuk mengaplikasikannya, literasi keuangan memberikan dampak yang baik dalam merencanakan dan mengambil setiap keputusan dalam berinvestasi.

Dengan memiliki pengetahuan tentang keuangan yang cukup atau bahkan lebih baik diharapkan masyarakat atau para investor mampu untuk memilih investasi dan mengambil keputusan dalam investasi yang tepat dan sesuai dengan yang diharapkan oleh investor yakni mendapatkan tambahan pendapatan atau menghasilkan keuntungan yang diinginkan (Budiarto A., \& Susanti, 2017)

Berdasarkan Survei Nasional 2013 dan 2016, Otoritas Jasa Keuangan (OJK) melakukan survei nasional terhadap 8.000 responden yang tersebar di 40 wilayah pada 20 Provinsi dengan hasil survey menunjukkan masyarakat Indonesia memiliki literasi keuangan dalam pasar modal sebesar 3.8\% pada tahun 2013 dan sedikit meningkat ditahun 2016 sebesar 4.40\%. Dari hasil survey tersebut bahwa masyarakat Indonesia masih memiliki tingkat literasi keuangan dalam pasar modal yang rendah. Dengan adanya literasi keuangan 


\section{Iskandar Budiman et al.}

Financial literacy, regrets experienced, excessive confidence, investment decisions

diharapkan para investor dapat memaksimalkan tingkat keuntungan yang diperoleh (budiato \& Susanti, 2017).

Experienced regret merupakan penyesalan yang timbul akibat kesalahan masa lalu yang mempengaruhi keputusan di masa depan. Para investor yang pernah mengalami penyesalan terhadap investasi selalu memikirkan baik-baik untuk menentukan investasi yang dijalaninya, risiko dalam setiap pengambilan keputusannya dalam investasi karena investasi tidak hanya keuntungan yang didapatkan tetapi juga terdapat risiko yang selalu ada dalam investasi yang dipilih. Experienced Regret yang dialami seseorang bisa saja seperti kerugian yang didapat dari investasi yang dilakukannya.

Tabel 1.

Observasi Experienced Regred Galeri Investasi IAIN Langsa

\begin{tabular}{|c|c|c|c|}
\hline No & Nama & Saham yang Dimiliki & $\begin{array}{l}\text { Kerugian } \\
\text { (2018) }\end{array}$ \\
\hline \multirow{2}{*}{1} & \multirow{2}{*}{ Fahmi Ramadhansyah } & TRAM (PT Trada Alam Mineral) & $30 \%$ \\
\hline & & GZCO (Gozco Plantations Tbk) & $21 \%$ \\
\hline 2 & Nadia & ADRO (Adaro Energy) & $2.18 \%$ \\
\hline 3 & Dewi Maulida & ANTM (Aneka Tambang) & $2 \%$ \\
\hline 4 & Nurasmalia & BRIS (Bank Rakyat Indonesia Tbk) & $9.98 \%$ \\
\hline \multirow{2}{*}{5} & \multirow{2}{*}{ Mursyida } & RODA (Pikko Land Development Tbk) & $34.25 \%$ \\
\hline & & BRIS (Bank Rakyat Indonesia Syariah) & $5.5 \%$ \\
\hline 6 & Elfiana Sari & TRAM (PT Trada Alam Mineral) & $5 \%$ \\
\hline 7 & Kasmawati & MPPA (Matahari Putra Prima Tbk) & $13.66 \%$ \\
\hline 8 & Lungguh Jati Negara & IKAI (Intikeramik Alamsari Industri) & $14 \%$ \\
\hline 9 & Chandra Jefrianto & ANTM (Aneka Tambang) & $3 \%$ \\
\hline 10 & Indah Lestari & BUMI (Bumi Resources Tbk) & $7 \%$ \\
\hline
\end{tabular}

Disisi yang berbeda, overconfidence juga dapat mempengaruhi pengambilan keputusan investasi, ketika seseorang telah mencapai suatu keberhasilan dan nyaman dengan bentuk investasi yang mereka lakukan, tingkat kepercayaan diri para investor meningkat dalam melakukan bentuk investasi lain yang mereka pilih di masa yang datang. Tingkat kepercayaan diri yang terus meningkat yang menyebabkan para investor tersebut Overconfidence (Wardani \& Iramani, 2014).

\section{KAJIAN PUSTAKA}

\section{Investasi}

Menurut Fradikasari \& Isbanah (2018), Investasi merupakan menyimpan dana pada saat tertentu dengan harapan dapat menghasilkan keuntungan di masa depan sehingga untuk melakukan investasi para investor memerlukan informasi penting yang dapat menentukan pilihan investasi. Dari informasi yang didapat, seseorang dapat mengambil suatu keputusan berinvestasi yang terbaik menurutnya. Beberapa produk investasi dikenal sebagai surat berharga atau efek. Surat berharga ialah suatu instrumen bentuk kepemilikan yang dapat dipindahtangankan dalam bentuk surat berharga, saham, obligasi, bukti utang, bunga atau 
Jurnal Manajemen Strategi dan Aplikasi Bisnis,

Volume 4, Nomor. 2, 2021. 321-330

partisipasi dalam suatu perjanjian reksadana, hak untuk membeli suatu saham. Investasi merupakan keikutsertaan modal kita dalam pengembangan perusahaan atau proyek dengan tujuan mendapatkan pembagian laba.

Abi (2012:11) menyatakan bahwa Investasi adalah sebuah aktivitas yang bertujuan untuk mendapatkan keuntungan di masa mendatang dengan memanfaatkan modal atau aset di masa sekarang. Investasi adalah aktivitas ekonomi seperti pembelian dari modal barang yang tidak dikonsumsi tetapi digunakan untuk produksi yang akan datang. Susanto (2012:3) Yang perlu di pahami tentang investasi yaitu adanya risiko, dan itu harus dimengerti sejak mengambil keputusan untuk berinvestasi, sehingga apapun return (imbal hasil) yang didapat oleh investor selalu berbanding lurus dengan risikonya. Jika seseorang menerima untuk risiko yang besar maka ia akan menerima imbalan yang besar, tetapi investor yang tidak menerima resiko maka akan mendapatkan imbalan yang rendah.Abi (2012:4) Investor adalah pemilik modal yang akan membeli atau menanamkan modalnya di perusahaan yang melakukan emisi. Sebelum membeli surat berharga yang ditawarkan, investor biasanya melakukan penelitian dan analisis tertentu.

\section{Keputusan Investasi}

Keputusan Investasi berkaitan dengan bentuk investasi yang dipilih yang dapat membawa keuntungan bagi investor. Bentuk penilaian dalam keputusan investasi dapat dilihat dari persentase investor dalam menentukan dana yang akan diinvestasikan dipasar modal. Menurut Harmono (2011:98) Keputusan investasi adalah kebijakan lain dalam manajemen keuangan, yaitu keputusan pendanaan dan kebijakan deviden. Investasi modal sebagai aspek utama kebijakan manajemen keuangan karena investasi adalah bentuk alokasi modal yang realisasinya menghasilkan keuntungan atau keuntungan dimasa yang akan dating.

Tandellin (2011:54) Keputusan investasi pada dasarnya terdiri dari: (1) return (tingkat pengembalian). Manfaat berinvestasi adalah memperoleh keuntungan. Dalam manajemen investasi tingkat keuntungannya disebut dengan return. Return yang diinginkan investor dari investasi yang dilakukannya merupakan bentuk kompensasi atas biaya kesempatan dan risiko penurunan daya beli akibat pengaruh inflasi. (2) risk (risiko). Korelasi langsung antara pengembalian dengan risiko, yaitu semakin tinggi pengembalian, semakin tinggi risiko. Oleh sebab itu, investor harus menjaga tingkat risiko dengan pengembalian yang seimbang.

\section{Pasar Modal}

Menurut Undang-Undang No. 8 Tahun 1995 pasar modal adalah kegiatan yang bersangkutan dengan penawaran umum dan perdagangan Efek, perusahaan public yang berkaitan dengan Efek yang diterbitkannya, serta lembaga dan profesi yang berkaitan dengan Efek. Pasar modal merupakan wadah untuk melakukan transaksi perdagangan berbagai instrumen keuangan jangka panjang, seperti: Surat utang, ekuitas, reksadana, instrument derivative maupun instrumen lainnya.

Abi (2012:3) Transaksi jual beli efek pasar modal dilakukan di Bursa Efek, yaitu pihak yang menyelenggarakan dan menyediakan sistem dan atau sarana untuk mempertemukan penawaran jual dan beli efek pihak lain, tujuannya adalah memperdagangkan efek diantara mereka. Pasar modal merupakan sebuah sarana yang dapat digunakan oleh emiten atau perusahaan yang membutuhkan dana untuk ekspansi usaha serta pihak investor yang 
Iskandar Budiman et al.

Financial literacy, regrets experienced, excessive confidence, investment decisions

membutuhkan tempat untuk berinvestasi sehingga memperoleh keuntungan dari investasi di pasar modal.

Pasar modal dibolehkan sesuai dengan Fatwa Dewan Syariah Nasional (DSN) Majelis Ulama Indonesia (MUI), fatwa DSN No: 40/DSN-MUI/X/2003 tentang Pasar Modal dan Pedoman Umum Penerapan Prinsip Syariah di Bidang Pasar Modal.

Menurut Abi (2012:3) Peranan pasar modal yaitu sebagai sarana penambah modal untuk memperlancar usaha. Perusahaan menjual saham ke pasar modal untuk memperoleh dana. Saham-saham ini dibeli oleh masyarakat umum, perusahaan lain, atau pemerintah. Pasar modal juga sebagai sarana pemerataan pendapatan, setelah jangka waktu tertentu saham yang telah dibeli memberikan deviden. Oleh karena itu, penjualan saham melalui pasar modal dapat dianggap sebagai sarana pemerataan pendapatan dan sarana peningkatan kapasitas produksi. Dengan adanya tambahan modal yang diperoleh dari pasar modal, maka produktivitas perusahaan meningkat. Sebagai sarana terciptanya tenaga kerja. Keberadaan pasar modal dapat mendorong muncul dan berkembangnya industri lain yang berdampak pada terciptanya lapangan kerja baru. Sebagai sarana peningkatan pendapatan Negara. Setiap deviden yang dibagikan kepada pemegang saham dikenakan pajak. Adanya tambahan pendapatan melalui pajak dan mengakibatkan pendapatan Negara. Sebagai indikator perekonomian Negara. Aktivitas dan volume transaksi jual beli di pasar modal yang semakin meningkat member indikasi bahwa aktivitas bisnis berbagai perusahaan berjalan dengan baik dan sebaliknya.

\section{Financial Literacy/ Literasi Keuangan}

Literasi Keuangan merupakan pengetahuan, keterampilan, dan keyakinan yang dipengaruhi sikap dan perilaku untuk meningkatkan kualitas pengambilan keputusan dan pengelolaan keuangan dalam rangka mencapai kesejahteraan (OJK, 2017).Hutami (2018) Mengatakan bahwa Financial Literacy berhubungan dengan kesanggupan seseorang untuk mengolah keuangannya. Literasi keuangan adalah kemampuan individu untuk memilih jasa keuangan, mendiskusikan tentang masalah keuangan, dan mempersiapkan keuangan masa depan yang mengakibatkan keputusan keuangan. Literasi keuangan merupakan suatu hal yang penting bagi setiap orang yang berfungsi untuk mengelola financial atau pendapatan yang dihasilkan oleh seseorang tersebut untuk kesejahteraan dimasa depan.

$\mathrm{H}_{1}$ : financial literasi berpengaruh signifikan terhadap pengambilan keputusan investasi

\section{Experienced Regret}

Experienced regret adalah pengalaman dalam berinvestasi yang dialami seseorang yang membuat orang tersebut menyesal dan kecewa dalam pengambilan keputusan investasi. Hal tersebut akan menjadikan seseorang lebih cermat dan hati-hati untuk melakukan investasi dan menghitung tingkat risiko lebih teliti dalam mengambil keputusan untuk berinvestasi (Hutami, 2018).Experienced regret adalah pengalaman yang dialami seseorang yang menyebabkan orang tersebut menyesal atau kecewa dalam pengambilan keputusan investasi dan atau orang tersebut lebih mampu untuk mempelajari risiko apa yang akan diterima dan dapat menerima risiko hasil pengambilan keputusan terdahulu. Jadi dapat disimpulan bahwa seseorang yang mempunyai keberanian yang besar dalam mengambil bentuk investasi yang 
Jurnal Manajemen Strategi dan Aplikasi Bisnis,

Volume 4, Nomor. 2, 2021. 321-330

memiliki risiko tinggi itu telah siap untuk menghitung tingkat risiko yang dapat ditimbulkan oleh keputusan investasi yang diambil (Widiastutik, 2018).

$\mathrm{H}_{2}$ : experied regret berpengaruh signifikan terhadap pengambilan keputusan investasi

\section{Overconfidence}

Overconfidence merupakan perasaan percaya diri yang berlebihan, keinginan seseorang dalam menaksi terlalu tinggi pengetahuan, kemampuan, dan ketepatan tentang informasi yang mereka miliki, dimana sikap ini mempengaruhi investor dalam berperilaku mengambil resiko (Hutami, 2018). .

Overconfidence merupakan keyakinan yang tidak berargumen dalam pikiran insting seseorang, perhitungan, dan kemampuan psikologis. Konsep overconfidence berasal dari percobaan psikologi dan peninjauan dimana subjek menambah-nambahkan kemampuan dan ketepatan informasi yang mereka berikan (Budiarto \& Susanti, 2017).Dalam penelitian Ellen dan Yuyun dikemukakan bahwa perasaan overconfidence merupakan perasaan terlalu percaya diri secara berlebih. Perilaku ini mengakibatkan hal yang tidak baik jika mengambil keputusan dalam berinvestasi. Tindakan tidak rasional yang membuat seorang investor perkiraan pengetahuan dan kemampuan yang dimilikinya terlalu berlebihan tanpa memikirkan risiko yang didapat nantinya. Seorang investor yang memiliki tingkat overconfidence yang tinggi maka lebih menaksir terlalu tinggi terhadap pengetahuan yang dimiliknya, yang memprediksi bahwa akan mendapatkan keuntungan lebih besar dalam melakukan investasi (Pradikasari \& Isbanah, 2012:11).

$\mathrm{H}_{3}$ : overconfidance berpengaruh signifikan terhadap pengambilan keputusan investasi

\section{METODE PENELITIAN}

Penelitian ini bermaskud menjelaskan pengaruh antar variabel melalui pengujian hipotesis dan melakukan eskplansi beberapa variabel, maka sifat peneltian ini adalah penelitian eskplanasi (explanation research). Penelitian ini menggunakan pendekatan kuantitatif, instumen pengumpulan digunakan seperti angket, daftar wawancara dan lainnya.

\section{Populasi Penelitian}

Populasi dari penelitian ini adalah seluruh investor Galeri Investasi IAIN Langsa. Berdasarkan data yang didapat dari Galeri Investasi IAIN LANGSA bahwa investor yang terdaftar di GI IAIN Langsa berjumlah 200 investor tahun 2019.Penelitian ini menggunakan penarikan sampel nonprobability sampling, yaitu pengambilan sampel dimana tidak semua anggota populasi berpeluang sama untuk menjadi sampel, dan menggunakan jenis quota sampling, yakni penetuan sampel dengan menentukan sampel dalam batas-batas jumlah tertentu sesuai dengan kebutuhan dan kecukupan analisis (juliandi \& Irfan 2013: 53).

Menurut Jugyanto (2007:79) Menetukan jumlah sempel dari suatu populasi menggunakan quota sampling berdasarkan kriteria tertentu sesuai dengan penelitian yang dilakukan peneliti. Kriteria tersebut yaitu seluruh investor yang aktif bertransaksi minimal satu hari beberapa kali bertransaksi dan maksimal sebulan sekali transaksi dan investor yang pernah mengalami kejadian buruk dalam investasi saham seperti kerugian tetapi masih aktif bertransaksi. Berdasarkan penelitian yang dilakukan oleh peneliti terdapat 45 investor yang aktif bertransaksi walaupun pernah mengalami kerugian dalam investasi saham. Jadi sampel 


\section{Iskandar Budiman et al.}

Financial literacy, regrets experienced, excessive confidence, investment decisions

yang diambil peneliti yaitu 45 responden yang aktif bertransaksi minimal satu hari beberapa kali dan maksimal satu bulan sekali serta pernah mengalami kerugian dalam investasi saham.

\section{Pengukuran}

Dalam penelitian ini teknik pengumpulan data menggunakan kuesioner. Kuesioner adalah pertanyaaan yang disusun oleh peneliti untuk mengetahui tanggapan responden penelitian tentang variabel yang diteliti. Financial Literacy, Experienced regret, dan overconfidenceakan menggunakan skala likert. Skala likert digunakan untuk mengukur respon subyek ke dalam 5 poin skala yaitu sangat tidak setuju, tidak setuju, netral, setuju dan sangat setuju.

\section{Teknik Pengambilan dan Pengumpulan Data}

Teknik pengumpulan data penelitian merupakan upaya untuk mengumpulkan sampel data yang berkaitan bagi peneliti. Teknik pengumpulan data dapat dilakukan dengan menggunakan teknik observasi, teknik wawancara, teknik studi dokumentasi, teknik penyebaran kuesioner. Dalam penelitian ini teknik pengumpulan data menggunakan kuesioner dan studi dokumentasi. Kuesioner adalah pertanyaaan yang disusun oleh peneliti untuk mengetahui tanggapan responden penelitian tentang variabel yang diteliti. Studi dokumentasi yaitu teknik mengumpulkan data dengan melihat data-data seperti dokumen tentang laporan keuangan, data dari otoritas jasa keuangan.

\section{Analisis data regresi linear berganda}

Metode analaisis data yang digunakan dalam penelitian ini adalah analisis regresi linear berganda. Juliandi \& Irfan (2013:169). Analisis regresi berganda bertujuan untuk menganalisis apakah model regresi yang digunakan dalam penelitian adalah model yang baik. Jika model baik maka data yang dianalisis layak untuk dijadikan rekomendasi untuk pengetahuan atau pemecahan masalah praktis. Adapun rumusnya adalah sebagai berikut:

$\mathrm{Y}=\mathrm{a}+\mathrm{b}_{1} \mathrm{X}_{1}+\mathrm{b}_{2} \mathrm{X}_{2}+\mathrm{b}_{3} \mathrm{X}_{3}+\mathrm{e}$

\section{HASIL DAN PEMBAHASAN}

Bedasarkan hasil perhitungan pengolahan data dengan program SPSS 20.00 maka diperoleh persamaan regresi linear berganda pada Tabel 2 .

Tabel 2.

Analisis Regresi

\begin{tabular}{ccccc}
\hline & Koefisien & SE & t & Sig \\
\hline (Costant) &, 618 & 2,402 &, 257 &, 798 \\
X1 &, 049 &, 142 &, 344 &, 733 \\
X2 &, 701 &, 161 & 4,359 &, 000 \\
X3 &, 321 &, 121 & 2,654 &, 011 \\
R_squaer & & & & \\
F- Statistic & 14,145 & & & \\
\hline
\end{tabular}

Sumber: Data Primer diolah pada SPSS 20, 2020 
Hasil dari analisis regresi berganda pengaruh financial literacy, experienced regret, dan overconvidence terhadap pengambilan keputusan investasi di pasar modal, yaitu ditunjukkan sebagai berikut

$$
\begin{aligned}
& Y=\alpha+b_{1} x_{1}+b_{2} x_{2}+b_{3} x_{3} \\
& Y=0,618+0,049\left(x_{1}\right)+0,701\left(x_{2}\right)+0,321\left(x_{3}\right)
\end{aligned}
$$

\section{Pembuktian Hipotesis}

Pembuktian pertama dengan menggunakan uji t dengan penjelelasan sebagai berikut:

Financial Literacy. Berdasarkan Tabel diatas menunjukkan bahwa nilai (X1) thitung dari financial literacy sebesar 0,344 < dari tabel sebesar 1,689, dengan nilai signifikasi sebesar 0,733 > alpha 0,05 Artinya financial literacy berpengaruh negatif dan tidak signifikan terhadap pengambilan keputusan invetasi di pasar modal.

Experienced Regret. Berdasarkan Tabel diatas menunjukkan bahwa nilai (X1) thitung dari experienced regret sebesar 4,359 >ttabel sebesar 0,294, dengan nilai signifikasi sebesar 0,000 < alpha 0,05 . Artinya experienced regret berpengaruh positif dan signfikan terhadap pengambilan keputusan investasi di pasar modal.

Overconfidence. Berdasarkan tabel diatas diatas menunjukkan bahwa nilai (X1) thitung dari overconfidence sebesar 2,654 >ttabel sebesar 1,689, dengan nilai signifikasi sebesar 0,011 < alpha 0,05 . Artinya overconfidence berpengaruh positif dan signfikan terhadap pengambilan keputusan investasi di pasar modal.

Pengujian hipotesis yang menyatakan ada pengaruh secara simultan (keseluruhan) financial literacy, experienced regret, dan overconfidence terhadap pengambilan keputusan investasi di pasar modal di Galeri Investasi IAIN Langsa dapat dilihat dari hasil uji F pada tabel. Nilai $F_{\text {hitung }}=14,145>F_{\text {tabel }} 2,81$ dengan nilai signifikan $=0,000$. Dengan demikian nilai signifikan $(0,000<0,05)$, maka terdapat pengaruh yang signifikan antara financial literacy (X1), experienced regret (X2) dan overconfidence (X3) terhadap pengambilan keputusan investasi di pasar modal (Y).

\section{KESIMPULAN}

Berdasarkan hasil penelitian dan pembahasan, maka dapat ditarik beberapa kesimpulan sebagai berikut. Pertama, financial literacy berpengaruh negatif dan tidak signifikan terhadap pengambilan keputusan investasi di pasar modal. Kedua, experienced regret berpengaruh positif dan signifikan terhadap pengambilan keputusan investasi di pasar modal. Ketiga, overconfidence berpengaruh positif dan signifikan terhadap keputusan investasi pada produk pasar modal di Galeri Investasi IAIN Langsa. Artinya semakin tinggi overconfidence investor GI IAIN Langsa maka semakin tinggi keputusan untuk membeli saham. Berdasarkan hasil pengujian hipotesis secara simultan (keseluruhan) terdapat pengaruh yang signifikan antara financial literacy, experienced regret dan overconfidence terhadap pengambilan keputusan investasi di pasar modal di Galeri Investasi IAIN Langsa.

\section{Implikasi}

Bagi peneliti selanjutnya disarankan menambah variabel independen yang dapat mempengaruhi pengambilan keputusan investasi produk pasar modal khususnya saham. Pada penelitian ini peneliti bisa memenuhi sampel sebesar 22,5\% karena keterbatasan waktu dan keterbatasan jumlah responden yang mau mengisi angket. Bagi penelitian selanjutnya juga diharapkan menggunakan data yang lebih akurat dengan jumlah responden yang lebih banyak untuk hasil yang lebih baik.Bagi investor galeri investasi IAIN Langsa diharapkan 


\section{Iskandar Budiman et al.}

Financial literacy, regrets experienced, excessive confidence, investment decisions

untuk lebih meningkatkan pengetahuan dan kemampuan dalam berinvestasi saham sehingga dapat meminimalisir kerugian

\section{DAFTAR PUSTAKA}

Abi, F. P. (2012). Semakin Dekat dengan Pasar Modal Indonesia. Yogyakarta: Deepublish.

Ady, S. U. (2017). Analisis Fundamental, suku bunga, dan Overconfidence terhadap pengambilan keputusan investasi pada investor di Surabaya. Ekspektra: Jurnal Bisnis dan Manajemen,, $1(2), 138-155$.

Agung, A. P. (2012). Metode Penelitian Bisnis. Malang: UB Press.

Ahmad, G. N., Lestari, R., \& Dalimunthe, S. (2017). Analysis Of Effect Of Profitability, Assets Structure, Size Of Companies, And Liquidity To Capital Structures In Mining Companies Listed In Indonesia Stock Exchange Period 2012-2015. JRMSI-Jurnal Riset Manajemen Sains Indonesia, 8(2), 339-354.

Budiarto, A. (2017). Pengaruh financial literacy, overconfidence, regret aversion bias, danrisk tolerance terhadap keputusan investasi (studi pada investor PT. Sucorinvest central gani galeri investasi BEI universitas negeri surabaya). Jurnal Ilmu Manajemen (JIM), 5(2).

Azuar, J., \& Irfan. (2013). Metode Penelitian Kuantitatif untuk Ilmu-ilmu Bisnis. Bandung: Citapustaka Media Perintis.

Eka Putri Widyastutik, D. (2018). Pengaruh experienced regret, risk tolerance dan jenis pekerjaan terhadap pengambilan keputusan investasi saham di surabaya (Doctoral dissertation, STIE PERBANAS SURABAYA).

Enterprise, J. (2014). SPSS. Jakarta: PT. Elex Media Komputindo.

Fauziah, A. Pengaruh Literasi Keuangan, Faktor Demografi, dan Pelatihan Analisis Teknikal terhadap Pengambilan Keputusan Investasi (Studi Kasus: Finance Club FEM IPB 2017/2018).

Harmono. (2011). Manajemen Keuangan Berabasi Balance Scorecard Pendekatan Teori, Kasus, dan Riset Bisnis. Jakarta: Bumi Kasara.

Hutami, C. W. (2018). Pengaruh Literasi Keuangan, Overconfidence, dan Persepsi Risiko terhadap Pengambilan Keputusan Investasi. Surabaya: Sekolah Tinggi Ilmu ekonomi Perbanas.

Jugiyanto. (2007). Metode Penelitian Bisnis: Salah Kaprah dan Pengalaman-pengalaman. Yogyakarta: BPFE-Yogyakarta.

KKBI. (2020, September 20). kbbi.we.id. Retrieved from kbbi.we.id: kbbi.web.id

Lubis, A. N., \& dkk. (2013). Perilaku Investor Keuangan. Medan: USU Press.

Munandar, A. (2014). Effects Of Size, Profitability, And Growth Rate Towards Capital Structure. Jurnal Dinamika Manajemen, 2(3), 153-159.

Musdalifah. (2016). Pendidikan Sarjana Pengaruh Locus Of Control, Financial Knowladge, dan Income terhadap Keputusan Berinvestasi Masyarakat Kota Makasar. Makasar: UIN Alauddin Makasar.

Nasional, D. S. (No: 40/ DSN-MUI/X/ 2003). Pasar Modal dan Pedoman Umum Penerapan Prinsip Syariah di Bidang Pasar Modal.

Otoritas Jasa Keuangan. (2014, Desember 30). Konferesnsi Pers Akhir Tahun 2014 Pasar Modal Indonesia. Retrieved from http:/ / www.ojk.go.id/ .30 Desember 2014

Otoritas Jasa Keuangan. (2016, Oktober 13). Survei Nasional Literasi dan Inklusi Keuangan. Retrieved from www.ojk.go.id

Otoritas Jasa Keuangan. (2017, November 17). Strategi Nasional Literasi Keuangan Indonesia. Retrieved from www.ojk.go.id

Pradhana, R. W. (2018). Pengaruh Financial Literacy, Cognitive Bias, dan Emotional Bias terhadap Keputusan Investasi (Studi Pada Investor Galeri Investasi Unviersitas Negeri Suarabaya). Jurnal Ilmu Manajemen, Vol 6 No.3. 
Pradikasari, E., \& Yuyun, I. (2018). Pengaruh Financial Literacy, Illusion Of Control, Overconfidence, Risk tolerance, dan Risk Perception terhadap Keputusan Investasi Pada Mahasiswa di Kota Surabaya. Jurnal Ilmu Manajemen, 6(4).

Republik Indonesia. (2019). Buku II Nota Keuangan Beserta Rancangan Anggaran Pendapatan dan Belanja Negara. (Tahun Anggaran 2019).

Riski Ayu Pratiwi Batubara, T. Z. (2017). Pengaruh Struktur Aktiva, Ukuran Perusahaan, dan Profitabilitas Terhadap Struktur Modal (Studi Pada Perusahaan Makanan dan Minuman yang Terdaftar di Bursa Efek Indonesia Tahun 2012-2015). Jurnal Administrasi Bisnis (JAB) |Vol. 50 No. 4 September 2017|.

Sari, D. A. (2018). Pengaruh Literasi Keuangan, Overconfidence, dan Risk Tolerance terhadap Keputusan Investasi Produk Pasar Modal. Bogor: Institut Pertanian Bogor.

Sholikhadi, L. M., \& Yahya, Y. (2016). Faktor-Faktor yang Mempengaruhi Struktur Modal Perusahaan Kosmetik dan Keperluan Rumah Tangga di BEI. Jurnal Ilmu dan Riset Manajemen (JIRM), 5(7).

Sunyoto, D. (2012). Analisis Validasi \& Asumsi Klasik. Yogyakarta: Gava Media.

Supratikno, H. (2011). Ekonomi Nurani \& Ekonomi Naluri. Jakarta: Yayasan Pustaka Obor Indonesia.

Susanto, H. (2012). Cerdas Memilih Investasi. Jakarta: PT.Elex Media Komputindo.

Tandelin. (2011). Portofolio dan Investasi. Yogyakarta: PT. Konisius.

Undang-Undang No. 8 Tahun 1995. (1995). Pasar Modal. Pasal 1 Ayat 3.

Undang-Undang No. 8 Tahun 1995. (1995). Pasar Modal. Pasal 3 Ayat 1.

Wardani, A. K., \& Lutfi, L. (2017). Pengaruh literasi keuangan, experienced regret, risk tolerance, dan motivasi pada keputusan investasi keluarga dalam perspektif masyarakat Bali. Journal of Business and Banking, 6(2), 195-214.

\title{
Competing interests
}

The authors declare that they have no competing interests.

\section{Funding.}

The authors received no financial support for the research and publication of this article.

\begin{abstract}
About the Authors
Dr. Iskandar, MCL is a senior lecturer in Fiqh Muamalah (Islamic Economic Law) at Economic and Bussines Islam Faculty in Islamic Institute State of Langsa. He hold the doctorate from National University of Malaysia. He has researched in various issues in Fiqh Muamalah, especially those related to Islamic Economic Law and Islamic Economic Management and has also been a speaker at various seminars, on Fiqh Muamalah, Islamic Economic and Management of Islamic Finance.
\end{abstract}

Zefri Maulana, S.E., M.Si is a lecturer at the Faculty of Islamic Economics and Business, Langsa State Islamic Institute, Aceh in the field of accounting.

Dr. Safwan Kamal, M.E.I. is a lecturer at the faculty of Islamic Economic and Islamic business, IAIN Langsa, Aceh in the field of Islamic Economic 